\title{
RECREATIONAL USE VALUE OF SHERANA VALLEY IN DUHOK GOVERNORATE, KURDISTAN REGION OF IRAQ
}

\author{
Silav Sadiq Hasan ${ }^{*}$, GHariba Yousif Haji ${ }^{*}$, Araz Bahjat Abdullah*, \\ HAJI YAZDEEN HAJI ${ }^{* *}$, HonAR SAFAR MAHDI ${ }^{*}$ and SAMI YOUSSEF ${ }^{*}{ }^{* * *}$
}

*Dept. of Recreation and Ecotourism, College of Agricultural Engineering Sciences, University of
Duhok, Kurdistan Region-Iraq.
${ }^{* *}$ Shingal technical institute, Duhok Polytechnic University, Kurdistan Region-Iraq
${ }^{* * *}$ University of Montpellier/Cirad/Cnrs/Inra/Ird - Amap, Cirad Ta A51/Ps2, Montpellier- France.

(Received: September 2, 2020; Accepted for Publication: January 18, 2021)

\begin{abstract}
Ecotourism and outdoor recreation are becoming one of the most attractive activities in the economic developments mainly due to their relaxation aspects for reducing the daily urban stress. While, debates continue about selecting the best strategies for recreational activities management, due to natural resources and finance limitations. Thus, estimation of economic value and benefits of recreation sites require allocating optimum resources of scarce. The economic evaluation of the recreation impact has been observed by few studies in Kurdistan region of Iraq. The current study aimed to determine the effect of demographic and socio-economic features of tourists on recreation demand, tourist use value in term of (Travel Cost trip, The Demand Function model and Calculation of the Consumer Surplus). The results showed that there was a slight difference between genders, graduates degrees and job career to visit Sherana valley natural tourist destination. Interestingly, most of the ecotourist visited the Sherana Valley for the opportunity to experience the beauty and magic of its great outdoors $(55.5 \%$ and $22.5 \%$ respondents did their first-, and second-time visits, respectively). Moreover, the difference between families income has a great effect on the visits. The findings showed that the average value of total travel cost was 24472.5 per tourist per visit and the most interesting finding was that the annual number of tourists visit affected by the travel cost, household income, age, and education level were not compatible with theoretical expectation in the travel cost implementation. Hence the consumer Surplus was estimated in this study to be 862069 ID ( 690 US\$). Due to the lack of database in this domain further researches need for other sites that qualify as a natural destination of recreation.
\end{abstract}

KEYWORDS: Recreation, ecotourism, Sherana valley, travel cost, Natural destination, Tourist.

\section{INTRODUCTION:}

$\mathrm{R}$ ecreation activities play a key role in sustainable development and especially improving the living standards of the rural people both in the short and long term via the commercial, investment, facilities, services and recreational activities. There is an increasing demandon outdoor recreation due to their relaxation activities and increasing population. But, there is a limitation in financial and natural resources for recreation. Hence, it requires estimation of economic value and benefits of recreation sites to allocate optimum resources of scarce (Limaei, et al, 2014). The development of economic is often related with a rising of demand on ecosystem services (Hasan and Matee, 2016). Even though the value of economic is one of different values that show a group or person actions depending on some considerations whether or not are gaining financially as an outcome of their actions, in addition there are some economic values for the environment (Leh, et al., 2018).Raphael and Molina (2007) highlighted that to incorporate the passive and direct use of environment to total economic framework is total economic value. One or multi trip mean to travel of individual to a site due to some reasons and factors (Menkhaus and Lober, 1995) as well as one or multi trip destinations mean to visits of tourists to more than one tourist site. Clough and Meister, (1991) recorded that individual travel of meanders and pure visitors category only should be taken in consideration.

The Travel cost methods are the best methods that used all over the world to assess the economic value of recreation and tourism 
services for example wildlife sanctuaries, forests and parks (Mitchell and Carson, 1989). TCM concept is by using cost of individual's travel data as a proxy for the value of recreational areas (Turner et al., 2008) the consumers' willingness can apply the basis of this method to pay the concept of (WTP) for the visiting cost of recreation areas (Turner et al., 2008). There are some money the visitors should pay for instance tolls, fuel, and parking, as well as the cost during their staying at recreational site for example ticket, food and accommodation should take in consideration. Moreover, Englin and Shonkwiler, (1995) recorded that using TC method, the expenses that associated with tourism travel will treated as a cost of travel as an aggregating out of pockets related with the time that spent in travelling and the travelled distance. Furthermore, these expenses in getting incurred to the area will be proxy for the paid price by the visitors for the use of area. This price allows the demand function estimation as well as consumer surplus estimation of activities and areas of recreation by area calculation the above price implicitly and below function demand (Freeman, 1993). Nevertheless, also there is some points of weakness exist in this approach based on benefit estimation approach (Whitehead et al., 2000).

Kurdistan region of Iraq is famous by its unique historic tourist attractions, cultural richness, and diversity of landscape (Youssef et al., 2019). The richness of diversity encourages a lucrative opportunity and interesting for investment in Recreation and tourism activities (Tourist Guide, 2005). Despite nature-based tourism benefits, the Kurdistan region of Iraq is not so good known to the local people and investment is poorly applied (Bahjat et al 2019). Moreover, the concept of recreation has been challenge recently by rural/local residents that is demonstrate the misunderstanding of opportunity that come from recreation which will improve rural people livelihood (Bahjat et al, 2019). Castro, (2013) mentioned that in many countries nature-based tourism considered as an alternative economic to the families. The study of (Sharif, 2015) highlighted that social factors and income have effect on demand of tourism. Additionally, the powerful mechanism to transform the behaviour of environment of visitors is nature-based tours (Powell et al, 2012).

Despite the high goals set in the Kurdistan region of Iraq with regard to the recreation sector development, it has been observed that few researches have been done on the impact of determining economic of recreation location depending on a travel cost the researches done so far (Haji Yezdeen, 2020; Bahjat et al, 2019; Hasan and Matee, 2016). Therefore, the aim of the study is to determine the impact of demographic and socio-economic features of tourists to Sherana Valley and Tourist use value of Sherana Valley as natural touristic destination in term of (Travel Cost trip, The Demand Function model and Calculation of the Consumer Surplus).

\section{MATERIALS AND METHODS:}

\subsection{Study area:}

The current research study was conducted in Sherana valley (Fig. 1), one of the most visited Recreational sites in Duhok Governorate. This recreational destination located between latitude $37^{\circ} 3.098^{\prime} \mathrm{N}$ and longitude $43^{\circ} 39.793^{\prime} \mathrm{E}$ near Deralok town in the north Duhok governorate, Kurdistan region of Iraq (Fig. 1). The Sherna area site is mainly characterised by its impressive natural landscape diversity i.e. deep valley crossed by the Sherana River with many small splendid waterfall throughout the Gara mountain chains. This remarkable natural river canyon located on the northern aspect of Gara mountain range. It is often considered to be one of most natural beautiful destination for recreation activities in the summer season. From vegetation community structure standpoint, the Sherana Valley area consists largely of open Oak forest formation with a dense ground cover of herbaceous species (Youssef et al. 2019). From climatic standpoint, the Sherana Valley is under a continental Mediterranean condition with mild, wet winters and warm dry summers (Youssef et al. 2019): A major part of the precipitation falls in late winter to late spring (with annual rainfall around $1000 \mathrm{~mm} / \mathrm{year}$ ) contrasted by temperature conditions between the summer (mean daily max under $35^{\circ} \mathrm{C}$ ) and winter season (mean daily min around $0^{\circ} \mathrm{C}$ ) with snow cover frequently in the winter. According to the classification of Köppen-Geiger bioclimatic system (Peel et al., 2007), it corresponds to the CsasensuKoppen (warm temperate -summer dry - hot summer). Therefore, all these natural attractions together (landscape diversity, vegetation cover, river canyon, favourable climatic condition, etc.) are associated with recreational activities in Sherana Valley site. For that the researchers selected this natural touristic 
destination to evaluate and validate the recreational use value of Sherana Valley.

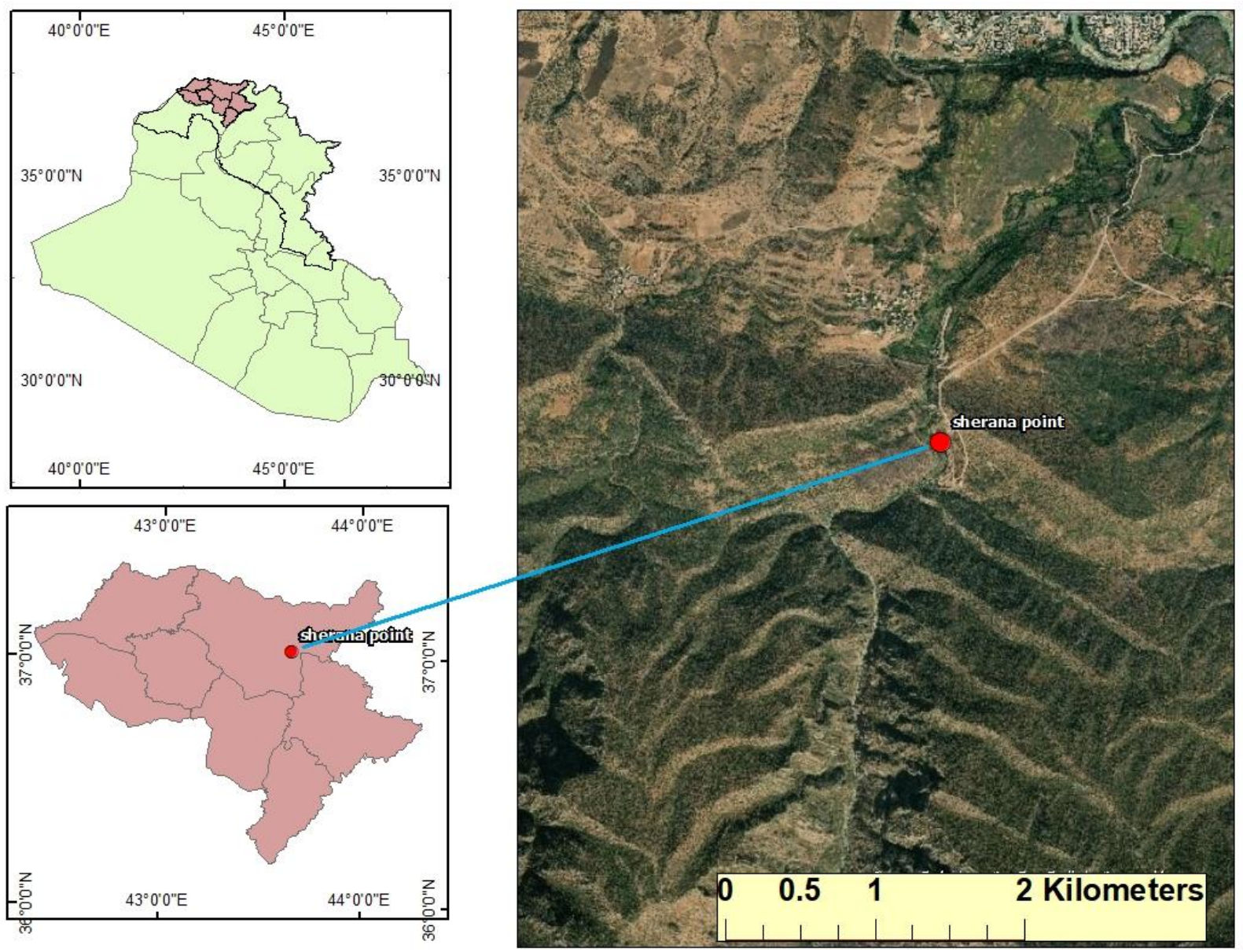

Fig. (1):- Location of Sherana Valley

\subsection{Data collection}

The field methodological framework of the current study was followed by the standard international methods for recreational use value (Maharana and Sharma, 1998; Hasan and Matee, 2016). The research achieved by collecting demographic, socio-economic and touristic information during structured interviews in Sherana Valley site. The stratified random sampling method used for the purpose of data collection (appendix 1). In total, the researchers distributed 225 questionnaire forms. Unfortunately, some of these forms were excluded due to the inappropriate answers or the absence of accurate data i.e. non-answered questions. The data collection phase was carried

\subsection{Data analysis:}

To assess the function of demand and the multiples factors affecting the Sherana Valley, the method Travel Cost (TC) was used (Hasan and Matee, 2016;Leh, et al., 2018). Indeed, the data was analyzed by individual travel cost method to determine the value of the tourism for out from May to October of 2019. Finally, out of the 225 questionnaire forms, 200 of them were used for statistical analysis.

Classically, the questionnaire design was divided in three main parts (appendix 1): The first part aims to take the demographical background information on respondents e.g. gender, occupation, education level, age, number of family member, type of trip, etc. The second part is mostly related to the general information on the touristic trip (number of time visits, attractions of the tourist sites their evaluation of the tourist site and their satisfaction level, etc.). While, the third part mainly focused on the travel costs i.e. total cost of the tripe, tourists' income, etc. (Table1). it, also the descriptive statistics approach, ANOVA and multiple Regression analysis were used to find the relationship between dependent and independent variables. In this complex's context, classically, the cost of visit to the recreation site, time cost and recreation site cost like entry fees are used as a proxy for price 
(Hanley and Spash, 1993). Consider the TC is the basic method which seeks how the visit frequency of consumer responds to variation in the price of visit. The basic promise of this method is that increase in the travel cost lead to decreasing number of visit. For the purpose of this study the following form of function used: Firstly, we calculated the individual travel cost method to quantify the tourism value of selected tourism destination according to the following equation:

$\mathrm{Vij}=\mathrm{B} 0+\mathrm{B} 1 * \mathrm{TTC}+\mathrm{B} 2 * \mathrm{Ag}+\mathrm{B} 3 * \mathbf{I n}+\mathrm{B} 4 * \mathbf{E L}$

Vij- Demand to visit the recreation site $\mathrm{i}$, for visitor $\mathrm{j}$.

TTC- total travel cost

Ag- visitor's age

In-visitor income per month

EL- Education level of visitors.

After then, ANOVA analysis and the multiple linear Regression model were conducted to measure the relationship between the dependent and independent variables as an essential step to estimate the tourist use value of Sherana Valley.
One this correlation dependent-independent variable is completed, the individual consumer surplus (CS) is calculated according to the equation developed by (Garrod, and Willis, 1999).



Where:

-Bij- Is the coefficient of travel costs.

-CS- is the consumer surplus per person per trip.

- q- represent the mean of number of trip during the year.

Finally, the total consumer surplus (TCS) of the tourist destination was calculated as follow:

TCS $=$ Annual NV*M.CS.........................(3)

Where:

-TCS- Total consumer surplus

- Annual NV-Annually number of visit

-M.CS- Mean of consumer surplus

\section{RESULTS\& DISCUSSION:}

3.1. Demographic and socio-economic features of tourists to Sherana Valley:

In recent years, there has been an increasing interest in recreation worldwide which plays a key role in sustainable development for each local/regional area (WSSD, 2002; Azimi, 2005). In this recreation revolution context, the demographic and socio-economic features of the tourists are at the heart of our understanding of the opportunities and challenges for local people and natural attraction areas (Bahjat et al., 2019). In Sherana valley recreation site, the results showed, based on 200 recreation surveys, a slight difference between the gender (53\% male versus $47 \%$ female) to visit natural tourist destinations (Table 1). This gender difference can be explained in part by the fact that the most recreation trips were done with family $(57.5 \%)$ or with friend $(39.5 \%)$ while insolate tripe represent only $3 \%$. This social aspect reflects the conservative feature of the Kurdish and MiddleEast society (Hasan and Matee, 2016). In addition, when visitors were analyzed depending on age category, a major part of visitors $(81 \%)$ were young categories between ages 18-30 (56 $\%)$ and $31-40$ age groups $(25.5 \%)$. This finding support previous research into this brain area that the recreational activities in this location suit younger people (Hasan and Matee, 2016). Interestingly, the results of the current study also showed that $61 \%$ of Sherana Valley visitors were graduated and diploma holders from university and $39 \%$ from under university degree (Table 1).

From job career standpoint, the visitors were evaluated depending on their profession groups where $25.5 \%, 32 \%$ and $16 \%$ of visitors were government employees, students and freelance, respectively. Income- Monthly income of visitors, concerning the income of the tourists visitors, the major part have $(71.5 \%)$ more than 
500,000 ID as income (e.g. 26.5\% had annual income more than 1000000 ID and around $13.5 \%$ of participant have $800000-900000$ ID) while only $28.5 \%$ have less than 500,000 ID as monthly income (Table 1). This last category is mainly represented by the students, housewife and freelance. This finding further support the idea of the importance of the recreation as a socio-economic crucial activities although the income of a part of tourists is low. Depending on the questionnaire system the researcher collected data about the number of visits to Sherana Valley; results about visitors' frequency are reported in table (1). One unanticipated finding was that most respondents $(55.5 \%)$ said that the current visits were their first visit to Sherana Valley while only 22.5 of visitors had more than three visitsand $12 \%$ had second-times visit. despite the natural attractive of the recreation destination but the services in the tourism site are not satisfied therefore the visit to this recreation site were not repeated. There are many natural areas and attractive landscapes are available in Kurdistan Region of Iraq especially in Duhok Governorate, however it needs more management planning and policies to conserve and develop (Hasan and Matee, 2016). Moreover, Kurdistan region of Iraq is famous by its unique historic tourist attractions, cultural richness, and diversity of landscape (Youssef et al., 2019). But it requires more discovering researches on recreation areas in the Kurdistan Region Iraq.

Table (1): Demographic and socioeconomic features of visitors to Sherana Valley

\begin{tabular}{|c|c|c|c|}
\hline \multicolumn{2}{|l|}{ Variables } & Frequency & Percentage \\
\hline \multirow[t]{2}{*}{ Gender } & Male & 106 & $53 \%$ \\
\hline & Female & 94 & $47 \%$ \\
\hline \multirow[t]{5}{*}{ Age } & $18-30$ years & 112 & $56 \%$ \\
\hline & $30-41$ years & 51 & $25.5 \%$ \\
\hline & $41-50$ years & 25 & $12.5 \%$ \\
\hline & $50-61$ years & 11 & $5.5 \%$ \\
\hline & More than 60 years & 1 & $0.5 \%$ \\
\hline \multirow[t]{2}{*}{ Marital Status } & Married & 117 & $58.5 \%$ \\
\hline & Single & 83 & $41.5 \%$ \\
\hline \multirow[t]{2}{*}{ Education Level } & Under University Degree & 78 & $39 \%$ \\
\hline & University Degree & 122 & $61 \%$ \\
\hline \multirow[t]{6}{*}{ Job or Career status } & Housewife & 31 & $15.5 \%$ \\
\hline & Student & 64 & $32 \%$ \\
\hline & Employee & 18 & $9 \%$ \\
\hline & Freelance & 32 & $16 \%$ \\
\hline & Pensioner & 4 & $2 \%$ \\
\hline & Government Employee & 51 & $25.5 \%$ \\
\hline \multirow[t]{5}{*}{ Satisfaction } & Very Unsatisfied & 6 & $3 \%$ \\
\hline & Unsatisfied & 9 & $4.5 \%$ \\
\hline & Natural & 41 & $20.5 \%$ \\
\hline & Satisfied & 70 & $35 \%$ \\
\hline & Very Satisfied & 74 & $37 \%$ \\
\hline \multirow[t]{4}{*}{ Number of trip } & One trip & 111 & $55.5 \%$ \\
\hline & Two trip & 24 & $12 \%$ \\
\hline & Three trip & 20 & $10 \%$ \\
\hline & More than four trip & 45 & $22.5 \%$ \\
\hline \multirow[t]{3}{*}{ Type of trip } & Alone & 6 & $3 \%$ \\
\hline & With family & 115 & $57.5 \%$ \\
\hline & With friend & 79 & $39.5 \%$ \\
\hline \multirow[t]{10}{*}{ Monthly Income } & Less than 200000 IQD & 14 & $7 \%$ \\
\hline & 200000-300000 IQD & 8 & $4 \%$ \\
\hline & $300000-400000$ IQD & 10 & $5 \%$ \\
\hline & $400000-500000$ IQD & 25 & $12.5 \%$ \\
\hline & 500000-600000 IQD & 20 & $10 \%$ \\
\hline & $600000-700000$ IQD & 11 & $5.5 \%$ \\
\hline & $700000-800000$ IQD & 12 & $6 \%$ \\
\hline & $800000-900000$ IQD & 27 & $13.5 \%$ \\
\hline & $900000-1000000$ IQD & 20 & $10 \%$ \\
\hline & More than 1000000 IQD & 53 & $26.5 \%$ \\
\hline
\end{tabular}




\subsection{Recreation use value of Sherana Valley}

\subsubsection{Travel Cost trip to Sherana Valley:}

In this recreation study, the researchers tried to calculate the tourist use value of the natural tourist destination at Sherana Valley through the use of the estimated consumer surplus mean. The first step to obtain this valuable recreation value of Sherana Valley is to estimate the total travel cost by visitors. On average the total travel costs was estimated according to multiple factors (e.g. time cost, accommodation cost other expenditure cost, etc.). It is apparent from the data of the current study that the average value of total travel cost was 24472.5 per tourist per visit. Knowing that the education level (E.L) with 0 for Under University Degree and 1 for University degree, age with 0 for more than 40 years and 1 for less than 40 years and income with 0 for less than 500000 ID and 1 for more than 500000ID they are considered as a dummy variables in a table 1.

$$
\begin{aligned}
& \text { Vij= } 1.118-0.00000232 \text { TTC-0.32011Age+ } \\
& 0.06181 \text { Incom+0.14835EL }
\end{aligned}
$$

Vij= Number of trip to studied location

TTC $=$ Total Travel Cost

E.L $=$ Education level of visitors

Beside the total travel cost, the relationship between the dependent and independent variables is a fundamental step to estimate the tourist use value of each natural touristic destination. In Sherana valley recreation context, the multiple linear regression modelsby stepwise was particularly used to identify the dependent variable i.e. the number of visit by tourists per year and the total travel costs of the independent variables i.e. the age, education level, and monthly household income categorises. The F statistics was in significant at 5\% which showed that the model was completely insignificant at $5 \%$ level. There sultsas show nine equation (1), indicate that there is no significant relationship between predictors and dependent variables. There are several possible explications for this non-significant relationship result. In fact, Sherana Valley is relatively a recent natural site in Duhok gournorate for recreational purpose and it's become popular recently only at local
Amadyia province) and/or regional (Badinan province) level however it is not yet popular enough at whole Kurdistan Region and Iraqi level. In addition, this non-significant relationship result should be interpreted with caution because a major part of the questioners have been taken by the residual people. Indeed, the non-popularity of Sherana natural site among Iraqi visitors can mainly be explained the lack of the tourism support services and infrastructure includes accommodation, restaurants, transport and other support services. Evermore notably, the Iraqi political issue and the degradation of the economic situation have considerably impacted and aggravated the recreational activities. Therefore, this small participation travel cost part of the visitors coming from south and middle of Iraq it let to minimizing the total travel cost.

Table (2): -Variance analysis (ANOVA Table).

\begin{tabular}{lllllll}
\hline Source & \multicolumn{7}{c}{ Th } & Df & Sum of Squares & Mean Square & F & Sig. \\
\hline $\mathbf{1}$ & Model & 4 & 6.07362 & 1.5184 & .97 & $.4243^{\text {a }}$ \\
\cline { 2 - 7 } & Error & 195 & 304.80138 & 1.56308 & & \\
\cline { 2 - 7 } & Total & 199 & 310.87500 & & \\
\end{tabular}

\subsubsection{The Demand Function model of Sherana Valley:}

In the current study, a multiple linear regression model (step wise) was used to calculate the consumer surplus and the demand function model of Sherana Valley natural tourist destination. The most interesting finding was that the annual number of tourists visit affected by the travel cost, household income, age, and education level were not compatible with theoretical expectation in the travel cost implementation (Table 3): one can investigate 
that the correlation between the number of visit (depended variable) and the total travel cost method is negative and identical to the logic of economic theory but it is insignificant. It seems possible that this negative and non-significant result is mainly due to the fact that the recreational activities have become one of the basic requirements of modern life. Therefore, the costs of the recreation trip did not have a significant effect on the frequency of visits as an evidence of the close distance of the natural touristic destination "Sherana Valley" to the Duhok governorate city and towns. This finding supports the study of Hasan and Matee (2016) that mentioned that most visitors like to go far away from their daily life routine.

Another important finding was that the frequency of visits to the Sherana recreation destination increasing during the touristic season "summer" for individual as their age decreases (Table $1 \& 3$. For example, the visitin rate was $81.5 \%$ for the touristic group under 41 years while only $18.5 \%$ of those who were interviewed have more than 41 years. Interestingly, this indicates that the Sherana recreation natural site attracts more young people and allow them to get far enough away from the hustle and bustle of city living.

The income variable also appeared in a direct and positive relationship with the dependent variable i.e. the number of visit to the recreation site during tourism season (Table 3). This finding is consistent to the economic principle which suggests that in general the individual's demand for luxury goods and recreation increases with the increase in family income. This can be illustrated by the fact that $71 \%$ of visitors have more than 500,000 ID monthly incomes. Likewise, the level of education variable appeared in direct and positive relationship with the adopted variable, as the number of individual visit increased as the educational level of the individual increased (Table $1 \& 3$ ). For example, $81.5 \%$ of the visitors have at least university degree level while only $18.5 \%$ have High school's degree or less. Interestingly, this indicated that the number of visit is positively correlated with the "educated and intellectuals" individual awareness of the importance of environmental quality and the health and psychology benefits provided by the recreational nature areas This interesting positive correlation is mainly due to the fact that the daily stresses of life (work stress, city crowds, etc.) in the city make hiking and entertainment an essential necessity of live, especially if the entertainment site is close to the site (Iamtrakul, et al., 2005; Hasan and Matee,2016).

Total number of visitor for sample study:

Total No. of visitors $=$ No. of married people *mean of family No. +No. of singles people

Total No. of visitors $=117 * 6.16+83=804$ number of visitors

Consumer surplus:

Consumer surplus $=-(\mathrm{q})^{2} / 2 \beta 1$

C.S $=-(2)^{2} / 2 *-0.00000232$

C.S $=862069$ ID

$-\mathrm{q}=$ mean of number of trip

$-\beta 1=$ Beta of total travel cost

\section{Total recreation value for destination sample} study

TRV for destination sample study= C.S*Total No. of visitors*mean of number of trip

TRV for destination sample study $=862069$ $* 804 * 2=1,386,206,952$ ID

Table (3): Multiple linear regression model results of Sherana Valley

\begin{tabular}{|c|c|c|c|c|c|c|c|}
\hline \multicolumn{2}{|l|}{ Model } & Variable & DF & $\begin{array}{l}\text { Parameter } \\
\text { Estimate }\end{array}$ & $\begin{array}{l}\text { Standard } \\
\text { Error }\end{array}$ & $\mathrm{T}$ value & $\operatorname{Pr}>|t|$ \\
\hline & & Intercept & 1 & 2.01132 & 0.20720 & 9.71 & $<0.001$ \\
\hline Age & 1 & -0.32011 & & 0.23584 & -1.36 & 0.1763 & \\
\hline EI & 1 & 0.14835 & & 0.19328 & 0.77 & 0.4437 & \\
\hline Inc & 1 & 0.06181 & & 0.18877 & 0.33 & 0.7437 & \\
\hline TTc & 1 & -0.00000232 & & 0.00000398 & -0.58 & 0.5617 & \\
\hline
\end{tabular}

a. Dependent Variable: number of trip

b. $\quad$ R Square $=0.0195$ 


\subsubsection{Calculation of the Consumer Surplus}

Traditionally, the consumer surplus provides a crucial overview value for the ecotourism sites. In the current study, the total consumer surplus (TCS) represents the tourism use value of Sherana Valley as a natural touristic destination. This TCS value of the tourist destination was calculated according to the equation number (3) (by multiplying the individual mean consumer surplus (CS, equation number (2) by the total annual visitors to the Sherana Valley touristic site. Indeed, the CS was estimated in this study to be 862069 ID ( 690 US\$). From the study sample (200 visitors), the total consumer surplus is calculated as follow:

\section{TCS $=$ Annual NV $*$ M.CS}

TCS $=100000 * 862069=86206900000 \mathrm{ID}$ ( 68965520 US\$). This value is the recreation value of Sherana Valley as one of the most natural touristic site in Kurdistan Region.

\section{CONCLUSION:}

The study aimed to investigate the impact of demographic and socio-economic features of tourists to Sherana Valley and Tourist use value of Sherana Valley as natural touristic destination in term of (Travel Cost trip, The Demand Function model and Calculation of the Consumer Surplus). The findings of this research showed for the first time in Kurdistan region of Iraq that had been done in Sherana Valley, most of the visitors to the area were Graduates in different degrees, as well as the visitors were preferred to trip with families rather than other categories. Moreover, most visitors were between age groups 31-40 years. Furthermore, the results showed that the annual number of tourists visits affected by the travel cost, household income, age, and education level was not compatible with theoretical expectation in the travel cost implementation. However, the total travel cost method is negative and identical to the logic of economic theory. The findings also showed that there was apositive relationship between number of travel to the tourist destination and independent variables (education level andand income). Nevertheless, the frequency of visits to the Sherana recreation destination were increased during the touristic season "summer" for individual as their age decreases thus allowing the young people $(<41$ years) to escape them from the daily stress of cities. The main prospective form this study is to conduct a first study in this domain and make this research as a fundamental step to estimate the tourist use value of each natural touristic destination, as well as a first step for further studies in this domain. Further researches are needed where visitors from middle and south of Iraq are included in the sample in order to obtain significant model and significant independent variables.

\section{REFERENCES:}

Azimi, N. (2005). The economics of tourismmaximizing the benefits of recreation for the locality.

Bahjatabdullah, a., şapciayas, z., \&mohammed, n. i. , (2019). Environmental impact of freshwater aquaculture on a nature based tourism site in north of Iraq, Duhok governorate. 4th international engineering and natural sciences conference (iensc 2019) (pp.1038-1047). Diyarbakir, Turkey

Castro, A. H. (2013). Nature-based tourism and its environmental message: the case of Pernambuco beaches, Brazil.

Clough, P. J., \& Meister, A. D. (1991).Allowing for Multiple-site Visitors in Travel Cost Analysis. Journal of Environmental Management, 32, 115-125.

Englin, J. and Shonwkiler, J.S. (1995) Modeling Recreation Demand in the Presence of Unobservable Travel Costs: Toward a Travel Price Model, Journal of Environmental Economics and Management, Vol. 29, 368377.

Freeman, A.M. III. (1993). the Measurement of Environmental and Resource Values: Theory and Methods. Resources for the Future, Washington, DC.

Hanley, N., \&Spash, C. L. (1993).Cost-Benefit Analysis and Environmental. England: Edward Elger Publishing Lim-ited.

Hasan, S. S .\&Zaki, M., A. (2016). Economic evaluation of recreation for selected forests locations in Duhok province (Master dissertation).Available from ProQuest Dissertations and Theses database. (College of Agricultural Engineering Science, University of Duhok)

Iamtrakul, P., Teknomo, K., \&Hokao, K. (2005). Public park valuation using travel cost method. In Proceedings of the Eastern Asia Society for Transportation Studies (Vol. 5, pp. 1249-1264).

Leh, F. C., Mokhtar, F. Z., Rameli, N., \& Ismail, K. (2018).Measuring Recreational Value Using Travel Cost Method (TCM): A Number of Issues and Limitations. International Journal of Academic Research in Business and Social Sciences, 8(10), 1381-1396. 
Limaei, S. M., Ghesmati, H., Rashidi, R., \&Yamini, N. (2014). Economic evaluation of natural forest park using the travel cost method (case study; Masouleh forest park, north of Iran). Journal of Forest Science, 60(6), 254261.

MaharanaS., and Sharma, E.(1998). Valuing recreation in a sacred lake of the Sikkim Himalaya, India. G. B. Pant Institute of Himalayan Environment and Development, 19.

Menkhaus, S., \&Lober, D. J. (1995). International Recreation and the Valuation of Tropical

Powell, R. B., Brownlee, M. T., Kellert, S. R., \& Ham, S. H. (2012). From awe to satisfaction: Immediate affective responses to the Antarctic tourism experience. The Polar Record, 48(2), 145.

Raphael, M.G. \& Molina, R. (2007). Conservation of Rare or Little-Known Species: Biological, Social and Economic Considerations. USA, Island Press.

Sharif D (2015). Tourism demand determinants of public employees in Iraq, Master's thesis, European university of Lefke, Cyprus.

Tourist Guide (2005).General Establishment of Tourism, Erbil, Northern Iraq 2014.

Turner, R.K, Georgiou, S. \& Fisher, B. (2008).Valuing Ecosystem Services: The Case of Multi-functional Wetlands. UK: Cromwell Press.
Rainforests in Costa Rica. Journal of Environmental Management, 47, 1-10.

Mitchell, R. C., Carson, R. T., \& Carson, R. T. (1989). Using surveys to value public goods: the contingent valuation method. Resources for the Future.

Peel, M. C., Finlayson, B. L., \& McMahon, T. A. (2007). Updated world map of the KöppenGeiger climate classification. Hydrology and earth system sciences discussions, 4(2), 439473.

Whitehead, J.C., Haab, T.C. and Huang, J. (2000) Measuring Recreation Benefits of Quality Improvements With Revealed and Stated Behavior Data, Resource and Energy Economics, Vol. 22, 339-354.

Garrod, G., and K. G. Willis. 1999. Economic Valuation of the Environment: Methods and Case Studies. Edward Elgar, Cheltenham, UK and Northampton, MA, USA: Edward Elgar.

WSSD (2002). Final Report, World Summit on Sustainable Development, Johannesburg.

Youssef, S., Galalaey, A., Mahmood, A., Mahdi, H. and Véla, E. (2019). Wild orchids of the Northern Iraq areas: a scientific window on the unexpected nature of the North-Western Zagros. 


\section{APPENDIX.1}

\section{Questionnaire}

\section{Email:}

Date

Time

Tourist destination (Tourist Area) :

Part 1 : Socio-economic characteristics

1. What is your gender?
$\square$ Male
$\square$ Female

2. Which of the following age groups do you fall into?

$\square 18-30 \quad \square 31-40 \quad \square$ 41-50 $\square 51-60 \quad \square$ more than 61 years

3-Marital Status.
口married
$\square$ single
$\square$ Widow

4. What is your highest level of education? (Please mark one box only.)

$\square$ Primary school $\square$ Secondary School $\square$ College Degree (bachelor). $\square$ M.sc. $\square$ PhD.

5. What is your job or career status?

$\square$ House wife $\square$ Student $\square$ Employed $\quad \square$ Freelance $\square$ Pensioner $\square$ Government employee

6. Which of the gross annual household income groups applies to you?

$\square-$ Less than 200000 ID $\square-200000-300000 I D \square-300000-400000 I D \square-400000-500000 I D \square-$ 500000-600000ID $\square \quad-600000-700000$ ID $\quad \square-700000-800000$ ID $\square-800000 \quad-900000$ ID $\square-900000-$ 1000000ID $\square-M o r e ~ t h a n 1000000 I D$

7. What is the type of trip?
aalone
$\square$ with family
$\square$ with group

8- Number of family member

\section{Part 2: General information}

1. If you don't mind me asking, where do you originally come from?

2. Is this the first time you have been to this tourism site?

$$
\square \text { Yes } \square \text { No }
$$

If No, how many times have you visited this tourism site during this season?

$\square$ One visit. $\square$ Two visits. $\quad \square$ Three visits. $\square$ more than 4 visits.

3. Will you come to this tourism site again in the future?
$\square$ Definitely
$\square$ Maybe yes $\square$ No, I will not visit again.

\section{How many times in the past year have you visited this tourism destination?}

$\square$ One time. $\quad \square$ Two times. $\quad \square$ Three times $\quad$ Four or more times. 
7. How satisfied are you about this tourist area?

Note: Use the following scale to rate your answers:
(1)= very satisfied (VS)
(2) $=$ satisfied $(S)$
(3) $=$ Neutral
(4) $=$ unsatisfied (US)
(5) $=$ Very unsatisfied

Tourist destination

$3 \quad 4$

$4 \quad 5$

Please write the name of the tourist destination you visited:

(------------------------------------------------------------)

8-Do you have anything more to say about your trip?

Part (3): Travel cost

1. Is This the only tourist destination on your trip?

$\square$ Yes $\square$ No

If No- Is ----------------- you're.......

$\square$ Main destination $\quad \square$ Secondary destination

$\square$ Minor destination (Tourist Opportunity)

2. What type of trip was this?
$\square$ Trip for one day
$\square$ Trip for several days

If not the one day trip, please answer question 3, 4 and 5:

If the day trip, please go directly to question 6:

3. How many nights did you stay in city? Number of night's

4. For how many people (including children) did you pay lodging expenses?

Number of people

5. How much did you spend on your accommodation for all the people you were responsible for per night? ID or $\$$.

6. Is the tourism site your only destination in Dohuk?

$$
\square \text { Yes } \quad \square \text { No }
$$

If No- Is this tourism site is yours:

$\square$ Main destination $\quad \square$ Secondary destination $\quad \square$ Minor destination

7- How many tourist destinations will you go to in Dohuk? - Destinations.

8. How did you travel to the tourism site?

$\square$ Tour bus $\square$ By private car $\square$ By taxi $\square$ Minibus. $\quad \square$ Other (please specify)

9. If you travel by private car. How many people traveled with you this time? peoples.

10. How much did you spend in the tourism site? ID or $\$$.

11. How much is the transportation fee per person to the tourist site for the following modes of transport?

$\square$ Tour Bus -ID or $\$ . \square$ Taxi ID or $\$ \square$ Minibus -ID or \$. $\square$ Others-------------ID or \$.

12. Travel time to access the tourism site was: (How much time you spent to get to the tourist site). Please circle one. 
a- (Less than $1 \mathrm{hr}$.)

b- (1.1-2hr.)

c-(2.1-3hr.) d- (3.1-4hr.)

e-

(more than 4 hrs.)

13. Time spent at a tourism site was: Please circle one

1- (Less than 3 hrs.) 2-( $3-6$ hrs.)

3-( 6-9 hrs.) 4-( 9-12 hrs.)

5-( more than 12 hrs.)

-Do you have other suggestions about tourism and tourist places in Kurdistan Region?

بهايسَ ب كارئينانا كهشتيارى بو كَليَّ شيرانه ل ياريَزكة ها دهوكى , هه ريَما كوردستانا عيراقَى

بوخته

كه شتيارى و نوريزما زينكههى د سروشتى دا يا بويه ئيك ز باشترين ئهكتفيتيا كو سهرهنجا خهلكى

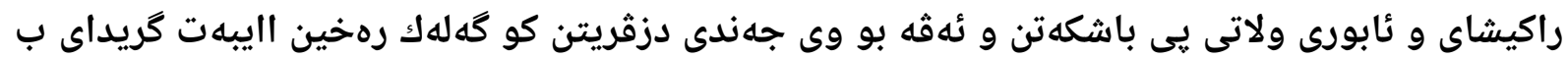

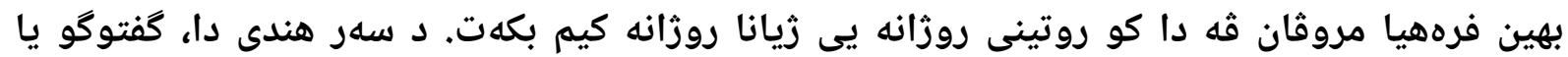
بهردهوامه ل سهر جهوانيا ههلبزارتنا باشترين ستراتيزييت ريفهبرنا ئهكتفتيين توريزما زينغههى ز زبه بهر كيميا زيدهرين سروشتى و كرفتين ئابورى. هوسا، ههلسهنغاندنا بها هو قازانجين ئابورى يين جهين

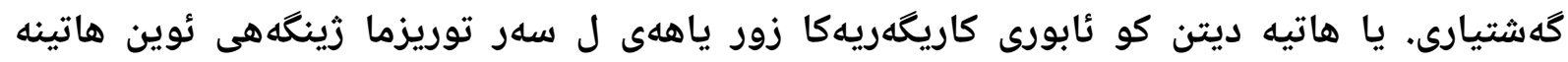
ئهنجامدان ل ههريما كوردستانا عيراقى. مهرهما مه ز ئهنجامدانا فى قهكولينى ز بو دئ دياركرنا كاريعهريا سيفهتين ديموگرافى و جفاكى و ئابوريا گهشتارى،بهايى هاتن و جونا گَهتيارى بو جهين سروشتى.

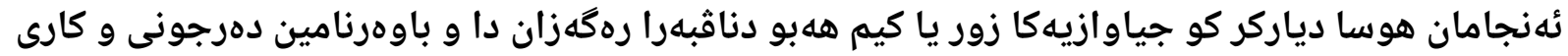
وانا دهما سهرهدانا گهليى شيرانه كرى، تشتى سهرهنج راكيش ئهوبو كهلهك ز گهشتارين سهرهدانا گهليى شيرانه كرى دا كو سروشتى وى ناوجى ببينن (55.5\% بو 22.5\%) د ديفكداسهرهدانين وانا ييت ئيكى و دووى بون. و ههروهسا جياوازيا دناقبهرا داهاتى خيزانان دا كاريگهريهكا مهزن ههبو ل سهر زمارا

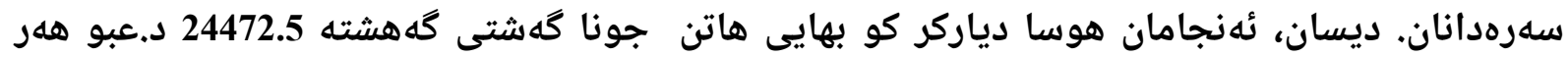

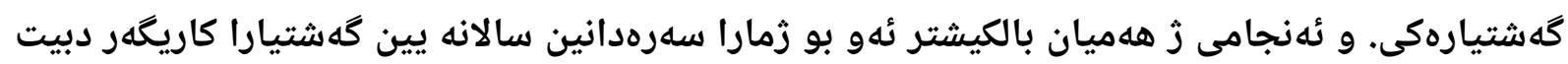

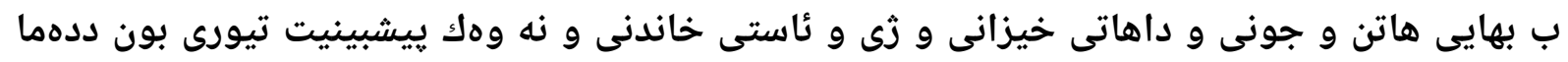

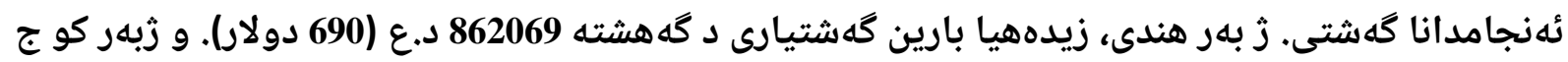

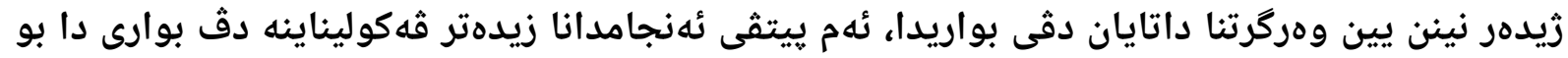
جهين دى يين توريزما زينغه هي. 
قيمة الاستخدام الترفيهي لوادي شيرانة فى محافضة دهوك, اقليم كردستان العراق

الخلاصة

أصبحت السياحة البيئية والاستجمام في اماكن الطبيعية واحدة من أكثر الأنشطة جاذبية في التنمية الاقتصادية ويرجع ذلك بشكل رئيسي إلى جوانب الاسترخاء الخاصة بها للحد من الإجهاد المدن اليومي.

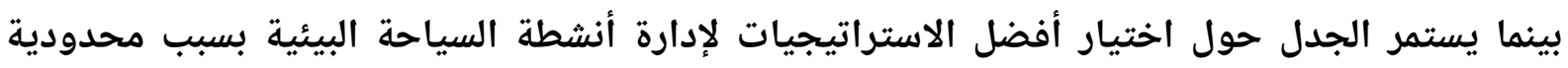
الموارد الطبيعية والجوانب المالية. وبالتالي ، يتطلب تقدير القيمة والفوائد الاقتصادية للمواقع الترفيهية تخصيص الموارد المثلى النادرة. وقد لوحظ التقييم ان الاقتصادي لها تأثير السياحة البيئية من خلال دراسات قليلة التي اجريت في إقليم كوردستان العراق. و تهدف الدراسة الحالية إلى تحديد تأثير الخصائص الديموغرافية والاجتماعية والاقتصادية للسياح، وقيمة استخدام السائح في فترة (تكلفة السفر

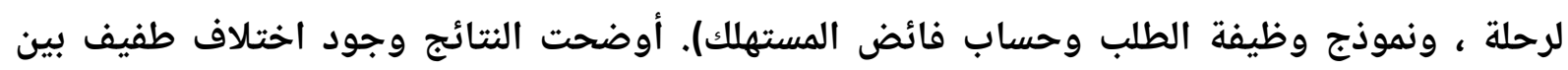
الجنسين وشهادات الخريجين والمهنة الوظيفية لزيارة الوجهة السياحية الطبيعية بوادي شيرانا. ومن

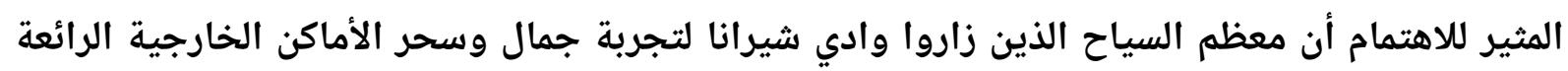

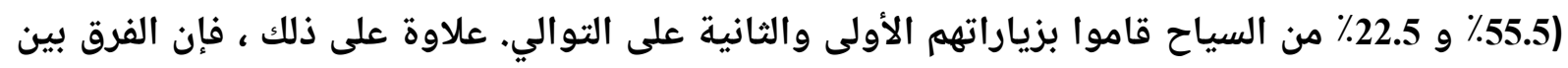
دخل الأسرة له أثر كبير على الزيارات ، فقد أظهرت النتائج أن متوسط قيمة إجمالي التوالئ تكلفة السفر كان24472.5 د.ع لكل سائح لزيارة واحدة ، وكانت النتيجة الأكثر إثارة للاهتمام هي أن الن العدد السنوي لزيارات السياح يتأثر بتكلفة السفر ودخل الأسرة والعمر ومستوى التعليم لم تكن متوافقة مع التوقعات

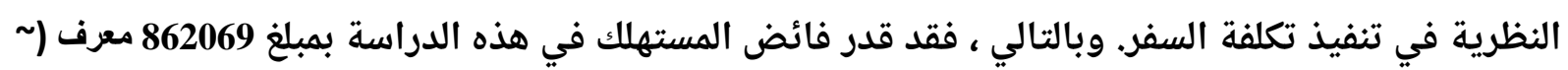

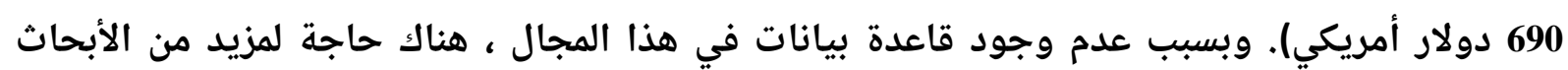
لمواقع أخرى مؤهلة لتكون وجهة طبيعية للسياحة البيئية. 